\title{
Plea Bargaining as Disaster
}

\author{
Stephen J. Schulhofert
}

Constitutional and doctrinal objections aside, plea bargaining seriously impairs the public interest in effective punishment of crime and in accurate separation of the guilty from the innocent. Unlike most defenders of American plea bargaining, Dean Robert Scott and Professor William Stuntz acknowledge these dangers. ${ }^{1}$ They pay close attention to prior research that has identified structural flaws in the bargaining system, and they make imaginative use of economic analysis to extend that work and reinforce its conclusions. But Scott and Stuntz do not take the next logical step and join those who have advocated the abolition of bargaining. Rather, they argue that abolition would make matters worse and that modest reform of the bargaining process can significantly reduce its harmful effects.

Unfortunately, the Scott and Stuntz proposals only nibble at the edges of the problem. Their suggested reforms would have little impact on the inefficiencies and injustices of the American plea bargaining system.

One might still choose to preserve rather than abolish bargaining, however, if Scott and Stuntz are right that abolition would aggravate existing problems. It is this feature of their argument that is most important, most original, and ultimately most disappointing. The Scott and Stuntz analysis does not successfully establish that abolition of bargaining would disadvantage the innocent. I argue, to the contrary, that abolition would serve both justice and efficiency.

Central to my thesis is an understanding of the structural problems that distort the plea bargaining system. Accordingly, Part I of this Comment explains how structural flaws impair both due process and crime control values. I argue that the subtle effects on the innocent that preoccupy Scott and Stuntz scarcely exist, except on paper, and that curing them would not, in any event, enhance the efficiency or fairness of the bargaining system. But I argue that other flaws in the bargaining structure, which Scott and Stuntz do not address, create massive problems of inefficiency and unfairness.

Part II of the Comment explains why the ameliorative reforms suggested by Scott and Stuntz are likely to prove ineffective. Part III focuses on the most

$\uparrow$ Frank and Bernice J. Greenberg Professor of Law and Director of the Center for Studies in Criminal Justice at the University of Chicago. I am grateful for the comments of William Landes.

1. Robert E. Scott \& William J. Stuntz, Plea Bargaining as Contract, 101 YALE L.J. 1909 (1992). 
interesting and consequential issue, the claim that a prohibition on bargaining would create even more serious problems than bargaining does, especially for the innocent. I show that economic analysis, properly understood, supports the opposite result. I therefore conclude that plea bargaining should be abolished. I suggest one way to implement such a reform without any additional expenditure by taxpayers, and a second method that would imply higher out-of-pocket expenses but net gains both for innocent defendants and for important though intangible public interests. In the language of economics, the benefits of abolition would greatly outweigh its costs. Stated more directly in the language of values that should inform a system of criminal justice, abolition is necessary to avoid egregious injuries that the American plea bargaining system currently inflicts on both innocent defendants and the law-abiding public as a whole.

\section{Structural Flaws in the Plea Bargaining System}

\section{A. The Presumptive Fairness of Voluntary Settlement}

Negotiated settlement of civil litigation does not seem prima facie suspect because we assume that the interested parties usually can make rational estimates of the costs of litigation and the expected gains from success at trial. If both parties believe that their interests are furthered by a negotiated pretrial settlement, such a result does not seem intrinsically unfair.

For similar reasons, negotiated resolution of criminal cases appears to serve the interests of all concerned. ${ }^{2}$ The prosecutor's objective in each case is to obtain the optimum level of punishment at the least cost, in order to free litigation resources for other prosecutions that can bring additional deterrence benefits. By tailoring each plea offer to the expected costs of trial, the likelihood of success, and the expected trial sentence, the prosecutor can maximize the deterrence obtainable from the finite resources at her disposal. Similarly, the defendant, who seeks to minimize punishment, will be better off accepting a plea offer if the contemplated punishment is lower than the anticipated posttrial sentence, discounted by the possibility of acquittal. Plea bargaining, from this perspective, not only saves court time and litigation costs, but serves both the public interest in maximizing deterrence and the defense interest in minimizing the expected sentence.

2. The most powerful and influential development of this thesis appears in Frank H. Easterbrook, Criminal Procedure as a Market System, 12 J. LEGAL STUD. 289 (1983). 


\section{B. The "Innocence" Problem}

The presumptive fairness of settlement, like that of any contractual exchange, can be questioned from a number of perspectives. ${ }^{3}$ Scott and Stuntz consider at length, and reject, the traditional objections based on duress, unconscionability, and incompetency. Yet they introduce a complex new objection drawn from bargain theory. They conclude that the plea bargaining "contract is inefficient because it fails to exploit the risk reduction potential of defendants' private knowledge [of his innocence]"4 and that "[r]isk averse defendants, meaning in part innocent ones, might well avoid [the possibility of conviction at trial] even at the cost of accepting a deal that treats them as if they were certain to be convicted at trial."

With its claims that plea contracts tend to pool innocent with guilty defendants, the Scott-Stuntz argument will seem intrinsically plausible (and attractive) to critics of plea bargaining. But Scott and Stuntz are not clear or consistent in specifying just what features of this situation they find problematic. When their argument is made more explicit, its plausibility and coherence fade.

In this section I attempt to spell out just what Scott and Stuntz mean by the "innocence problem." I make three points. First, the problem they emphasize is a barely perceptible theoretical ripple, not a real-world issue; its significance is dwarfed by monumental flaws in the bargaining structure that Scott and Stuntz do not address. Second, to the extent that this kind of innocence problem exists, reduced barriers to efficient contracting would not affect it. Third, the particular innocence problem the authors have in mind is not (if it exists) a problem at all. Only through a narrow contract model, which incorrectly posits the absence of externalities, can Scott and Stuntz conclude that barriers to bargaining with the innocent cause significant "inefficiencies." Thus, while plea bargaining does suffer from major defects, the particular information barriers that preoccupy Scott and Stuntz are not problematic and should not guide efforts to determine how plea bargaining should be reformed.

Just what is the "innocence problem"? For Scott and Stuntz, the barrier to effective contracting is that prosecutors can make only imperfect estimates of the likelihood of conviction at trial. If they could accurately identify the innocent defendant, prosecutors would realize that a conviction, though not impossible, is less likely than the strength of their file would imply; accordingly, they would offer a lower sentence in exchange for a plea. ${ }^{6}$ But since a prosecutor cannot get a reliable signal from a defendant about actual innocence,

3. See Owen M. Fiss, Against Settlement, 93 YALE L.J. 1073 (1984); Judith Resnik, Judging Consent, 1987 U. CHI. LEGAL F. 43.

4. Scott \& Stuntz, supra note 1 , at 1948.

5. Id.

6. As we shall see, Scott and Stuntz do not simply assume that prosecutors will dismiss charges against the innocent. Infra text accompanying notes 15-16. 
she has an incentive "to offer an innocent defendant the same deal that she would offer a guilty defendant with the same case file-with no downward adjustment." As a result "some percentage of innocent defendants who would have accepted a low-price offer will refuse the deal and win acquittals after a trial." Conversely, some innocents will accept the relatively high offer, despite substantial probabilities for acquittal at trial, because they are risk averse.

What features of this situation make it inefficient or unfair? From their frequent comments to the effect that bargaining "makes it harder for innocent defendants to identify themselves" and fails to "facilitate the separation of innocent defendants from guilty ones at the bargaining stage,"10 Scott and Stuntz appear concerned that bargaining will convict the innocent. Yet part of the authors' objection is that the innocent get unattractive offers, and as a result, innocent defendants "who would have accepted a low-price offer" instead "win acquittals after a trial." "From this perspective, the "pooling problem," for Scott and Stuntz, is not that the criminal justice system convicts the innocent, but that it presents the innocent and the guilty with similar offers and thus convicts fewer innocents than an "efficient" system would. ${ }^{12}$

The Scott and Stuntz article invites conflicting interpretations of this seemingly paradoxical conclusion. They may believe that information barriers prompting innocent defendants to refuse plea offers and get acquittals present an advantage that is outweighed by the more frequent situation in which riskaverse innocents accept offers that are too high.

Yet, carefully read, most of their analysis implies that the first situation (innocents who refuse deals) is itself undesirable. The innocent goes to trial and wins acquittal, even though he "would have accepted a low-price offer."13 Thus, the flawed bargaining structure prevents the parties from fully realizing "the risk reduction potential of defendants' private knowledge."14 The innocent defendant who gets acquitted is worse off than he would have been without information barriers because he has been forced to undergo the risk of conviction and a high sentence after trial, when he would have preferred the option of a plea offer with a low sentence. The prosecutor is also worse off. She is forced to incur litigation costs that she could have avoided if she had been able to exploit the risk reduction potential by presenting the innocent with an attractive offer. In addition, since for Scott and Stuntz the prosecutor's goal is to "maximize net sentences over the population of defendants," they state

\footnotetext{
7. Scott \& Stuntz, supra note 1, at 1947.

8. Id.

9. Id. at 1949.

10. Id. at 1950 .

11. Id. at 1947.

12. Id. at $1947-48$.

13. Id. at 1947.

14. Id. at 1948.

15. Id. at 1947.
} 
that acquittal of the innocent causes "losses to the prosecutor"16 because the prosecutor has failed to extract as much punishment as she could get by persuading this group to plead guilty.

This paradoxical conception of loss reveals one way that "efficiency" and the "innocence problem" are misspecified in the Scott-Stuntz model. Litigating cases against innocents is indeed inefficient (if avoidable), but inability to impose punishment on innocents is not a loss for prosecutors or anyone else. There is a broader difficulty here too. The "innocence problem," in its paradoxical Scott-Stuntz formulation, turns traditional objections to plea bargaining inside out. In a previous article, I discussed the same information barriers, but drew a much different conclusion about their implications for the innocent. ${ }^{17}$ I counted information asymmetry (the defendant knowing that he is innocent when the prosecutor does not) as a factor that might save bargaining from unfairness: it would leave innocent defendants more likely than guilty defendants to refuse any given offer and go to trial, where they could win acquittal. ${ }^{18}$ But I also noted that this advantage was undercut by the fact that "the prosecutor cannot distinguish the response [to her offer] of the innocent but highly risk-averse defendant from that of the guilty but less risk-averse defendant, and sorting mistakes (that is, conviction of the innocent) will occur."19

Scott and Stuntz do not address my analysis directly, but their argument suggests that I was wrong on both counts. For them, information asymmetry is inefficient when it prevents the innocent from negotiating acceptable plea offers leading to their conviction; conversely, if the innocent defendant finds a plea offer acceptable, the "sorting mistake" is not conviction of the innocent but only imposition of a different penalty than a system with effective price discrimination would inflict.

The Scott-Stuntz formulation of the "innocence problem" thus conflates two distinct and largely incompatible objections-a justice objection (that bargaining convicts too many innocents because they are risk averse and prefer settlement to the risk of a high sentence after trial) and a narrowly conceived efficiency objection (that bargaining convicts too few innocents because its flawed structure denies them their preferred option of settlement at a low sentence). Before discussing remedies, we must decide which of these problems we wish to solve. Is the appropriate goal to minimize convictions of the innocent? Or is it to minimize barriers to efficient contracting, so that innocents who prefer lowprice offers can negotiate acceptable plea agreements leading to conviction?

The originality of Scott and Stuntz' argument lies in their preference for the latter view. Their formulation of "efficiency" and the innocence problem

16. Id.

17. Stephen J. Schulhofer, Criminal Justice Discretion as a Regulatory System, 17 J. LEGAL STUD. 43 (1988).

18. Id. at 80 n. 97 .

19. Id. 
suggests that information barriers to variable-price contracting are undesirable and that reform should seek to make plea agreements easier for the innocent to reach. In the remainder of this section, I show that their argument, though provocative, is flawed on three counts. First, the information asymmetry that allegedly prevents effective price discrimination (the inability of a defendant credibly to signal his innocence) is a theoretical problem with little practical impact. Second, the information asymmetry does not, even in theory, have the distorting effects that Scott and Stuntz attribute to it. Third, to the extent that asymmetry does block plea agreements that the innocent might otherwise reach, this result is desirable, not "inefficient." Thus, I argue for an old-fashioned conception of what the "innocence problem" is, and for an old-fashioned kind of remedy-abolition of bargaining-to solve it.

The first point to stress is that the information asymmetry driving the ScottStuntz analysis is an exceedingly peripheral factor in the overall negotiation setting. Offers and reservation prices depend on the likelihood of conviction, which, in turn, is governed primarily by the admissible evidence available to the prosecution and defense. Although the prosecutor has no right to discover most exculpatory evidence that a defendant may offer at trial, the defendant has powerful incentives to disclose in negotiation any evidence that makes acquittal more likely. ${ }^{20}$ The defendant has no credible way to disclose actual innocence, but he can and normally will disclose evidence of innocence. ${ }^{21}$ Innocence by itself (that is, apart from its link to particular evidence) can have only a small impact on the odds of conviction. Thus, the problem (if it is a problem) that Scott and Stuntz want to solve has at most only incidental effects on the bargaining environment.

Second, when information asymmetry affects negotiations, it does not necessarily harm the innocent. If the prosecutor could be apprised of a defendant's belief in his own innocence, this information would convey two facts, not just one. It would indicate, as Scott and Stuntz stress, that conviction is less likely than the prosecutor's file would otherwise suggest, and this fact would prompt the prosecutor to lower her reservation price. But the possibility of innocence would also convey that the defendant is likely to be more risk averse than the prosecutor had thought (since she assumes that most defendants are guilty), and this fact would prompt the prosecutor to make a higher initial plea offer. Innocents who plead guilty under the current regime would still plead guilty after information barriers were lowered; and with less ability to hide their

20. See Steven Shavell, Sharing of Information Prior to Settlement or Litigation, 20 RaND J. ECON. 183 (1989). An important qualification is that voluntary disclosure may not occur when settlement seems unlikely and the exculpatory evidence will be more effective if the prosecutor can be taken by surprise.

21. Even demeanor and related intangibles bearing on the credibility of the defendant (and other witnesses) can be appraised by the prosecutor in pretrial interviews. A defendant who considers himself innocent is often willing to tell his story directly to the prosecutor (in the presence of his attomey), though this becomes unlikely once the prosecutor appears committed to bringing the case to trial. Cf. FED. R. CRIM. P. 11(e)(6)(D) (providing for inadmissibility of such statements made in course of plea discussions). 
risk aversion, they could wind up with plea contracts that were more severe. Defendants who now reject high-price offers, and thus go to trial, might elicit acceptable agreements because the prosecutor's reservation price would be lower. But if (as Scott and Stuntz assume) most innocents tend to be highly risk averse, the number of defendants who are able to reach agreement due to lower information barriers is likely to be much fewer than the number who would settle anyway but get less favorable terms after reforms because prosecutors would be aware of their attitudes to risk.

Conceivably, under just the right set of empirical conditions, it might be possible to help some innocents reach settlement without hurting an equal or greater number of innocents who would plead guilty under either regime. Would this change make the reformed system more "efficient"? Though practically and empirically unlikely, the Scott-Stuntz claim is nonetheless theoretically provocative because it suggests the "flaw" in the bargaining process is that it leads innocent defendants to elect trial. How could this possibly be an undesirable result?

The intuition behind the Scott-Stuntz argument is the conventional economic conception of the welfare-maximizing potential of voluntary transactions. Although it seems unfortunate that an innocent defendant would plead guilty in return for the low sentence that an efficient bargaining system would provide, that individual prefers this option to the risk of conviction followed by a higher sentence at trial. As Scott and Stuntz put it, the innocent defendant's dilemma is sad, but forcing him to trial against his wishes would be even sadder. ${ }^{22}$ The implication of their analysis, then, is that the existing plea negotiation framework is flawed because it convicts fewer innocents than would an "efficient" bargaining structure that minimized barriers to trade.

Why does this seemingly straightforward application of economic theory seem so troubling and counterintuitive? The Scott-Stuntz analysis neglects to make explicit an essential prerequisite for the efficiency of voluntary transactions, namely the absence of externalities. Voluntary contractual arrangements are presumptively efficient only when the parties fully internalize the social costs and benefits of their transactions. Yet litigation time, conviction, and punishment are quintessential public goods with pervasive effects external to the immediate settlement transaction.

Scott and Stuntz appear to assume that a plea bargain that is in the interest of an innocent defendant imposes no costs on those who are not parties to the agreement. ${ }^{23}$ This is obviously not the case, however, because conviction of the innocent produces serious negative externalities. As the Supreme Court stated in In re Winship:

22. Scott \& Stuntz, supra note 1, at 1960-61.

23. In a hypothetical economic "model," one might postulate that the prosecutor internalizes the social costs of convicting the innocent. But Scott and Stuntz do not take this approach, and to do so would render the prosecutor's objective function indeterminate. 
It is critical that the moral force of the criminal law not be diluted by a standard of proof [or a procedure for conviction] that leaves people in doubt whether innocent men are being condemned. It is also important in our free society that every individual going about his ordinary affairs have confidence that his government cannot adjudge him guilty of a criminal offense without convincing a proper factfinder of his guilt with utmost certainty. ${ }^{24}$

A large body of legal doctrine attests to the importance of assuring that innocents will not be convicted, whether or not they themselves would prefer to avoid the risks of a high sentence after trial. ${ }^{25}$ Such rules are "inefficient" only if the value of autonomy and the two-party gains of voluntary contracting outweigh the social costs of convicting the innocent. But that precarious argument is one that Scott and Stuntz do not attempt to make and that economic theory is incapable of demonstrating.

Though Scott and Stuntz draw no comparison between individual and social costs (because they disregard the latter), their argument reflects implicit sympathy with the individual, an innocent defendant. Abolition of plea bargaining would harm such a person, they argue, because it would deny the defendant a settlement option he prefers. The economic conception of "harm" (a reduction in an individual's aggregate welfare) is misleading in this context because bargaining and barriers to bargaining inflict qualitatively different kinds of injury. There is, justifiably, a strong social policy against punishing the innocent. But there is no comparable social policy against inconveniencing an innocent (for example, by requiring him to stand trial), if reducing his welfare in this way would benefit others. ${ }^{26}$

I conclude that the particular "innocence problem" invoked by Scott and Stuntz, though thought-provoking and theoretically complex, has little practical or institutional significance; if it exists at all, it should not be regarded as a "problem." But there are other structural flaws that do have serious implications for the faimess and efficiency of plea bargaining. Unlike the subtle issues of bargain theory that preoccupy Scott and Stuntz, the flaws they do not consider pose truly massive barriers to efficient transactions with welfare-maximizing potential for the parties concerned. The next section discusses the difficulties

24. In re Winship, 397 U.S. 358,364 (1970).

25. See, e.g., FED. R. CRIM. P. 11(f) (judge must find facual basis before accepting guilty plea); North Carolina v. Alford, 400 U.S. 25,38 (1970) (guilty plea was not invalid, despite defendant's protestations of innocence, where evidence "substantially negated [defendant's] claim of innocence"); Lynch v. Overholser, 369 U.S. 705 (1962) (trial judge correctly refused to accept defendant's guilty plea where psychiatric report indicated that defendant might be not guilty by reason of insanity); United States v. Cepeda Penes, 577 F.2d 754 (1st Cir. 1978) (not abuse of discretion for trial judge to reject nolo contendere plea when no factual basis for plea is shown).

26. Society does not permit individuals to contract out of jury duty or the military draft, even though voluntary agreements for such purposes would enhance the welfare of the immediate contracting parties. A refusal to permit innocents to negotiate out of the risky business of vindicating themselves at trial can be understood in similar terms. Of course, a defendant remains free to avoid the inconvenience of trial if he is willing to enter a nonnegotiated guilty plea and accept the punishment called for by the facts alleged. 
that should be at the center of an economic analysis of the welfare implications of plea bargaining.

\section{Distortions Due to Pervasive Conflicts of Interest}

The Scott-Stuntz critique, despite its economic sophistication, is premised on a simple bilateral bargaining situation. In reality, the negotiating framework is more complex. The real parties in interest (the public and the defendant) are represented by agents (the prosecutor and the defense attorney) whose goals are far from congruent with those of their principals. There is, accordingly, a potential for conflicts of interest or, in the language of economics, a problem of agency costs. The proposition that a mutually agreed-upon exchange presumptively enhances the welfare of both parties collapses, absent reason to believe that the agents are acting in the interest of their principals.

Scott and Stuntz acknowledge the agency cost problem, ${ }^{27}$ but they give it little attention, primarily because of their assumption that agency problems would become even more serious if plea bargaining were abolished. But to appreciate the full scope of structural distortions in plea bargaining, and to assess possible remedies, the dynamics of the agency relationships need detailed examination.

Consider first the prosecutor. Both the chief prosecutor (the District Attorney) and her assistants have numerous incentives to pursue goals that diverge from the public's interest in optimal deterrence. The District Attorney is usually an elected official, and whether elected or appointed, her goal is to enhance her reputation and her political standing. ${ }^{28}$ An effective crime control strategy could contribute to that goal, but deterrence effects at the margin (whether positive or negative) are likely to be imperceptible to the general public, especially over the short run. ${ }^{29}$ Several other factors (such as a high conviction rate, a good relationship with influential private attorneys, and an absence of high-profile trial losses) contribute more directly and more effectively to the District Attorney's political standing. The chief prosecutor will occasionally want to try a case that could be resolved more efficiently by settlement. More often, perhaps, she will want to ensure settlement, even if this requires overly generous plea offers. In either event, the chief prosecutor has powerful reasons for accepting plea agreements different from those that public interest considerations alone would generate.

Front-line prosecutors who actually negotiate plea agreements may or may not share the District Attorney's desire to enhance the office's political stature. Hence, there is an additional layer of agency problems in the relationship

27. Scott \& Stuntz, supra note 1 , at 1928. (1976).

28. See, e.g., Sam Peltzman, Toward a More General Theory of Regulation, 19 J.L. \& Econ. 211

29. See Schulhofer, supra note 17 , at 50-51, 65-66. 
between the chief prosecutor and her assistants. If the assistants can elude monitoring by their superior, and if they are committed to crime control, they can seek optimal sentences even at the expense of their chief's reelection chances. But the assistant's immediate goal is not necessarily to find the optimal strategy for controlling crime or even for reelecting his superior. Rather, his goal (in an economic model) is to maximize his own welfare, which is defined by some combination of career advancement, job satisfaction, and leisure. Pursuing an optimal crime control strategy may help advance the prosecutor's career, but other factors are likely to do so more effectively. The front-line prosecutor may gain by trying a case that the public interest would require to be settled. Conversely, the front-line prosecutor will often have powerful personal and professional reasons to avoid trying cases that would be inconvenient or potentially risky for his career. ${ }^{30}$

In sum, the prosecutor's position as an agent means that guilty plea settlements negotiated case by case tend to diverge from those that would most efficiently serve the public interest in optimal deterrence. This divergence usually takes the form of unduly lenient sentence offers.

On the defense side, agency problems are similar, though possibly more acute. Like prosecutors, defense attorneys sometimes have personal or professional reasons for trying a case when their clients would be better served by settlement. ${ }^{31}$ More often, defense attorneys have powerful incentives to avoid trial, even when a trial would be in the client's interest. The incentives vary with the particular form of the attorney-client relationship, but the net effect is nearly always the same-a sharp divergence between the economic interests of attorney and client, together with powerful financial incentives for the attorney to settle as promptly as possible.

These agency problems are probably least serious when a defendant has retained paid counsel. Attorneys compensated on an hourly basis generally do not face financial pressure to minimize the time spent on a case, so they do not have a personal incentive to settle quickly. But criminal defense attorneys are almost never paid in that fashion. Only a minority of criminal defense attorneys (as few as twenty percent in many urban jurisdictions) are retained by paying clients, and nearly all of those attorneys work for a flat fee paid in advance. ${ }^{32}$ Since court rules usually prohibit defense counsel from withdrawing once an appearance has been entered, a retained attorney is obliged to take her case to trial if settlement negotiations fail, and in that event, her additional services are rendered free of charge. Accordingly, financial pressure to settle is intense.

30. Id. at 51 .

31. It might seem that a prohibition on bargaining would not protect the defendant in such a case because it would force the very trial that defense counsel improperly recommended. But in a no-bargaining world, the defendant would not risk years of extra punishment as the price for the experience or publicity gained by his attorney.

32. Schulhofer, supra note 17 , at 53-54. 
Counsel appointed for the indigent serve under a variety of systems. Some are conscripted from the list of those admitted to the bar and are required to serve without any compensation whatsoever. ${ }^{33}$ Conscription may even extend to lawyers who lack any experience or expertise in criminal law. Although involuntary conscription without pay once seemed on the way to extinction, recent crises in municipal financing have resurrected this approach in many jurisdictions. ${ }^{34}$ Understanding the impact of such systems on the attorney's incentives to settle does not require a Ph.D. in economics. In some jurisdictions, conscription is coupled with some provision for attorney's fees. But services are compensated at rates that are invariably far below their market value, as is obvious from the fact that defense attorneys are not willing to serve voluntarily. Again, incentive effects hardly need to be spelled out.

Appointed attorneys in many jurisdictions volunteer for criminal defense work and are paid for their services. But in nearly all cases, compensation takes the form of either a flat fee per case, or a low hourly rate coupled with a ceiling on total compensation payable. A 1986 survey revealed that compensation caps as low as $\$ 500$ or $\$ 1000$ were common for felony cases, and some states enforced caps of $\$ 1000$ even in capital cases. ${ }^{35}$

These compensation limits are almost invariably identical for guilty plea cases and those that go to trial. And most states have little or no flexibility to waive compensation caps for unusually complex cases or those that elicit exceptional attorney effort. Thus, the attorney who counsels his client against accepting a plea must do so knowing that his time spent preparing and trying the case will be provided entirely free of charge. Occasionally, a foolish (or idealistic) attorney does take a case to trial under these conditions, earning compensation that may average one or two dollars per hour. ${ }^{36}$ More often, the results are in accord with economic theory. Attorneys either accept appointment with the expectation (and under the financial imperative) of convincing the client to plead guilty, or they refuse appointment altogether.

Conflict of interest problems are less dramatic for public defenders because they have no immediate financial incentive to avoid trial. But defender organizations, which are typically run as agencies of state or county government, ${ }^{37}$ have their own institutional needs, and they tend to develop a strong priority

33. See NATIONAL STUdy COMM'N ON DEFENSE SERVICES, GUTELINES FOR LEGAL DEFENSE SYSTEMS IN THE UNITED STATES: FNAL REPORT 261 (1976).

34. See David Margolick, Volunteers or Not, Tennessee Lawyers Help Poor, N.Y. TMME, Jan. 17, 1992, at B16.

35. See ROBERT L. SPANGENBERg \& PATRICIA A. SMITH, AN INTRODUCTION TO INDIGENT DEFENSE SYSTEMS 7-8 (1986); Marcia Coyle et al., Fatal Defense, NAT'L L.J., June 11, 1990, at 30, 32; Stephen J. Schulhofer, Access to Justice for the American Underclass, WORLD \& I, June 1991, at 463, 471-72.

36. See, e.g., Huskey v. State, 688 S.W.2d 417 (Tenn. 1985) (upholding fee of $\$ 500$ for 181 hours reasonably spent in noncapital felony-murder trial); MacKenzie v. Hillsborough County, 288 So. $2 d 200$ (Fla. 1973) (upholding $\$ 750$ fee for over 500 hours reasonably spent defending capital case).

37. See Bureau of Justice Statistics, U.S. Dep'T OF Justice, National CRIMINal Defense SYSTEMS STUDY 15 (1986). 
for moving their caseloads. The resulting organizational pressures for nontrial disposition, together with the attorneys' personal incentives, again lead to a sharp divergence between the trial-versus-plea preferences of the attorney and those of his client.

Two qualifications to the agency analysis need to be considered. First, because both prosecutors and defense counsel have interests that diverge from those of the parties they represent, both sides may lack sufficient zeal. As a result, the two sets of agency problems may cancel each other out. But we have no reason to expect that conflict of interest effects neatly balance one another in any particular case. More likely, agency problems generate inadequate deterrence in some cases and harm to defendants, especially innocent defendants, in others. Even from the aggregate perspective of economic theory, there is no reason to suppose that contracting under these conditions is efficient or maximizes the welfare of the parties concerned.

There is a second qualification. Agency problems are pervasive in complex economic transactions; they do not by themselves argue against the efficiency of voluntary contracts. Typically, the market generates mechanisms for monitoring and other contractual devices to reduce agency costs. Indeed, gains from trade normally must exceed agency costs, or principals will be unwilling to enter the market, and contracting will not take place. For plea negotiation, in contrast, no market-like solutions are available to protect either the public or the accused. The political process is not merely imperfect; it is intrinsically incapable of monitoring the optimality of prices negotiated by prosecutors in guilty plea contracts. ${ }^{38}$ On the defense side, reputation plays some role in encouraging loyalty by retained counsel to their clients' interests. But reputation effects are blurred by the extreme difficulty of extracting useful information about the quality of the bargain struck by an attorney in any particular case. ${ }^{39}$

In the case of indigent defendants, the problem is more basic. Indigents do not have, even in theory, the right to select their attorneys ${ }^{40}$ and court officials who make appointments have incentives to favor cooperative lawyers rather than the most zealous ones. ${ }^{41}$ While the principal-agent situation known to ordinary economic analysis is a chosen, contractual relationship with welfaremaximizing potential for all concerned, the relationship between a defense attorney and an indigent client is structured by the rules of court rather than by contract, and the arrangement is involuntary for one (and possibly both) of the parties.

38. See Schulhofer, supra note 17 , at $65-66$.

39. Id. at 59.

40. WAYNE R. LAFAVE \& JEROLD H. ISRAEL, CRIMINAL PROCEDURE § 11.4, at 546-47 (2d ed. 1992).

41. See BUREAU OF JUSTICE STATISTICS, supra note 37, at 18 (in over two-thirds of appointed counsel programs, appointment decision is made by individual judge rather than by public defender or independent court administrator). 
The subtle barriers to efficient contracting suggested by Scott and Stuntz thus pale in comparison to agency problems that pose massive obstacles to efficient, welfare-enhancing transactions. Prosecutors have few incentives to pursue an optimal deterrence strategy, and effective monitoring of bargaining strategy from outside the prosecutor's office is unattainable, in theory as well as in practice. On the defense side, the attorney-client relationship is not the voluntary contractual arrangement postulated by economic theory, but a partly or wholly involuntary relationship infected by pervasive conflicts of interest and the virtual nonexistence of effective means to monitor counsel's loyalty and performance in the low-visibility plea negotiation setting. These structural flaws inflict grievous damage both on innocent defendants and on the public interest in effective law enforcement. Any effort to rectify the inefficiencies and injustices of the plea bargaining system must focus primarily on these pervasive and central flaws.

\section{THE SCOTT-STUNTZ PROPOSALS}

Scott and Stuntz offer three proposals to remedy structural defects in bargaining. One proposal would bar mandatory minimum sentences attached to overbroad statutes, while using sentencing guidelines to control judicial discretion. ${ }^{42}$ The second would permit judges to revise bargained sentences downward. ${ }^{43}$ The third would make prosecutorial plea commitments binding, rather than subject to upward revision by the judge. ${ }^{44}$

While offered as a partial solution for what Scott and Stuntz call "the innocence problem," the three proposals have only a tenuous link to that problem. Instead, the proposals seem implicitly guided by more traditional conceptions of the problems faced by the innocent under plea bargaining, especially duress, mistake, poor judgment, and inadequate representation. This broadening of focus and sensitivity to practical problems enriches their analysis but leaves the precise objectives of their proposals uncertain. And unfortunately, their proposals (two of which are already widely used ${ }^{45}$ ) will do little to mitigate either the "innocence problem" as they conceive it or the problems of the innocent as more traditionally understood.

\section{A. Prohibiting Mandatory Minimums}

Scott and Stuntz are undoubtedly correct that mandatory minimums attached to overbroad statutes encourage strategic behavior that poses enormous risk for

\footnotetext{
42. Scott \& Stuntz, supra note 1 , at 1960-66.

43. Id. at 1957-60.

44. Id. at 1953-57.

45. See infra text accompanying notes 54,58 .
} 
the innocent ${ }^{46}$ Their vivid discussion of Bordenkircher v. Hayes ${ }^{47}$ forcefully illustrates the point. Repeal of mandatory minimums is amply justified, for that reason and many others. ${ }^{48}$

But as a major element in a plan to reform plea bargaining, the proposal to prohibit mandatory minimums has three serious shortcomings. First, it is only tenuously connected to the Scott-Stuntz program of facilitating the separation of the innocent from the guilty at the bargaining stage. The repeal of mandatory minimums would either increase the number of defendants who insist on trial (an inefficient result from their perspective), or leave essentially unchanged both the guilty plea rate and the proportion of innocents in the pool of defendants who are able to extract "low-price" plea offers. ${ }^{49}$

Second, the most striking advantage of the proposal, its reduction of the price at which innocent defendants would be persuaded to plead guilty, is simply a consequence of repealing an unjust background sentence. The innocent defendant who pled guilty would then suffer a less unjust sentence, as would the guilty defendant who pled guilty or the defendant (whether innocent or guilty) who was convicted at trial. The improvement is the inevitable consequence of repeal of an overly severe statutory sentence. The change is worth making because by hypothesis the sentence is unjust, but the change does not alter the structural dynamics of plea bargaining or benefit factually innocent defendants in any distinctive way.

Third, mandatory minimum sentences, though becoming more common and more important, ${ }^{50}$ still affect only a small portion of the criminal docket, especially in the state courts. The Scott-Stuntz proposal therefore would leave in place all the possibilities for strategic behavior and coercion of the innocent that flow from sentencing structures not governed by mandatory minimums.

46. Scott \& Stuntz, supra note 1 , at 1960-66.

47. 434 U.S. 357 (1978).

48. See U.S. SENTENCING COMM'N, SPECIAL REPORT to THE CONGRESS: MANDATORY MINIMUM PENALTIES IN THE FEDERAL CRIMINAL JUSTICE SYSTEM (1991). Repeal of mandatory minimums entails the cost of leaving substantial uncontrolled judicial discretion. Scott and Stuntz assume that this difficulty can be avoided by structuring the judge's discretion through sentencing guidelines. Scott \& Stuntz, supra note 1 , at 1966. But guidelines create substantial costs of their own, especially in the added adjudicatory costs of finding the facts necessary to determine the applicable guideline. In addition, guidelines do not necessarily control strategic behavior by prosecutors and may aggravate the problems of coercion of the innocent in plea negotiations. See Stephen J. Schulhofer \& Ilene H. Nagel, Negotiated Pleas Under the Federal Sentencing Guidelines: The First Fifieen Months, 27 AM. CRIM. L. REV. 231, 271-82 (1989); Stephen J. Schulhofer, Assessing the Federal Sentencing Process: The Problem is Uniformity, Not Disparity, 29 AM. CRM. L. REV. (forthcoming 1992).

49. Without mandatory minimums, when an innocent defendant rejected a prosecutor's initial plea offer, the prosecutor would no longer be able to respond with the "bump-up" strategy of threatening a severe posttrial sentence pegged to an unjust mandatory minimum. The prosecutor could instead respond with a "bump-down" strategy (reducing the guilty plea sentence rather than raising the posttrial sentence) to produce a comparable sentence differential between the plea and trial alternatives. The restriction on bargaining would not help prosecutors more effectively identify defendants who believe themselves to be innocent because it would apply to all defendants (whether innocent or guilty) who had significant ex ante prospects for acquittal at trial.

50. See U.S. SENTENCING COMM'N, supra note 48 , at 5-15. 
Why isn't an innocent defendant's decision to plead guilty equally problematic when prompted by strategic manipulation of very high sentences in statutes that are not overbroad? Scott and Stuntz believe that abolition of bargaining would only aggravate the dilemma of the innocent defendant charged with a serious offense. ${ }^{51}$ When such a defendant accepts a low-price plea offer, they argue, it is because the defendant himself prefers that option to the risk of conviction and the very high sentence after trial.

Posing the problem this way is justifiable only if, after abolition of bargaining, the innocent would face the same high sentence after conviction at trial. Because, by hypothesis, the posttrial sentence is not unequivocally "unjust," Scott and Stuntz assume that it would continue to confront innocent defendants after abolition of bargaining. But this cannot be the case because eighty to ninety percent of defendants currently plead guilty and receive sentences that are anywhere from twenty-five to seventy-five percent lower than those imposed on comparable defendants convicted at trial. ${ }^{52}$ Abolishing plea concessions without a change in the sentences imposed after conviction at trial would require massive increases in prison capacity, an unlikely prospect indeed. Holding punishment resources constant, abolition of plea concessions would require substantial reduction of posttrial sentences. The innocent defendant would still face an unpleasant situation-the risk of punishment in the event of conviction at trial and no option of a negotiated settlement. But his position would be no worse, prima facie, than that of the innocent defendant in today's world, who faces a higher sentence if he chooses trial and has only the option of a sentence discounted from the high, trial-penalty level if he pleads guilty.

\section{B. Permitting Judges to Revise Bargained Sentences Downward}

The second Scott-Stuntz proposal would authorize sentencing judges to impose sentences lower than those negotiated by the parties. ${ }^{53}$ Again, the proposal can do nothing to alter the special "innocence problem" that is the main Scott-Stuntz concern. A judge's power to reduce the agreed-upon sentence

51. Scott \& Stuntz, supra note 1 , at 1960-61.

52. The U.S. Sentencing Commission has estimated that in the federal system, pre-guidelines, the average difference between guilty plea sentences and those imposed after trial was 25-35\%. See Schulhofer \& Nagel, supra note 48, at $245 \mathrm{n}$.71. In some state courts, posttrial sentences can be two to four times higher than sentences imposed after a plea in a comparable case. See, e.g., Thomas M. Uhlman \& Darlene N. Walker, "He Takes Some of My Time; I Take Some of His": An Analysis of Judicial Sentencing Patterns in Jury Cases, 14 LAW \& Soc'Y REV. 323, 328 (1980) (in Iarge Eastern city, controlling for prior record and seriousness of charge, average sentence after jury trial was nearly three times more severe than average guilty plea sentence). An important qualification, however, is that "bargains" in many jurisdictions prove to be illusory, especially when judges use the low-visibility practice of "real-offense" sentencing to offset prosecutorial concessions. Where this practice still exists, posttrial and bargained sentences tend to converge. See, e.g., Stephen J. Schulhofer, Due Process of Sentencing, 128 U. PA. L. REV. 733, 757 (1980); H. Jo0 Shin, Do Lesser Pleas Pay?: Accommodations in the Sentencing and Parole Processes, 1 J. CRIM. JUST. 27, 34-35 (1973).

53. Scott \& Stuntz, supra note 1 , at 1957-60. 
would, if anything, tend to drive prosecutorial offers (and reservation prices) higher. Defendants would discount the "high-price" plea agreement to some degree by the prospect of winning a reduction from the judge. But assuming risk aversion, plea concessions with that feature would tend to be less attractive than a binding plea offer with the same ex ante expected value. Innocent defendants, who are likely to be the most risk averse, would be hurt by the Scott-Stuntz proposal; they would wind up either with less attractive plea agreements or with decisions to go to trial (a disadvantage, according to Scott and Stuntz) that they would not have made in the absence of prosecutorial compensations for the judge's power.

The real target of the Scott-Stuntz proposal is not the "innocence problem" in their restricted sense, but rather the more conventional concerns about problems of mistake, poor advice, and ineffective assistance. Scott and Stuntz correctly identify these as major problems that warrant substantial remedial action. But their own proposal is not up to the task.

Judicial authority to revise plea agreements downward already exists in all jurisdictions,${ }^{54}$ and this authority does little or nothing to remedy the problems of poor representation and mistake. Scott and Stuntz assume that a defense attorney's error will lead to a "bargained-for sentence that substantially exceeds the norm for the crime" and that the judge "is in a very good position to recognize unusually high sentences." 55 This analysis seems valid only with respect to one unusual class of attorney errors-those resulting from a lack of knowledge of the going guilty plea sentence for defendants with little or no chance of acquittal at trial. The far more important class of attorney error involves failure to develop or press available factual and legal defenses that would give the defendant a significant chance of acquittal. In that situation, the attorney may fail to explain to the defendant the advantages of rejecting a plea offer or fail to extract the best available concessions from the prosecutor. But there is no way that the judge can detect this kind of error when she reviews a plea agreement. As Scott and Stuntz themselves recognize "it is hard to judge a defense attorney's performance by his behavior in any one case."

Thus, once a defendant appears in court and announces his willingness to plead guilty, the judge has no practically effective capacity to recognize a bad bargain and rectify it by imposing a lower sentence than the one the parties negotiated. The judge may impose a lower sentence because the one negotiated is too harsh for a defendant clearly guilty of the facts charged, but the judge cannot be expected to identify and adjust for litigation risks and exculpatory evidence that the defense attorney herself failed to exploit in the course of negotiations. As a result, the power of downward revision proposed by Scott

54. Judges can always impose a sentence lower than the one negotiated by the parties, unless there is an applicable mandatory minimum. See, e.g., FED. R. CRIM. P. 11(e)(3)-(4).

55. Scott \& Stuntz, supra note 1 , at 1959.

56. Id. 
and Stuntz (and already in place in all jurisdictions) can make little or no contribution to rectifying the problems of inadequate representation and mistake.

\section{Making Prosecutorial Plea Commitments Binding on the Judge}

The authors' third proposal is the most consequential. Barring judges from increasing sentences negotiated by prosecutors would facilitate pleas in cases where both parties recognize that the probabilities of conviction are low. ${ }^{57}$ This proposal does not address the problem of asymmetric information because it comes into play only when the existing negotiating situation elicits the information necessary for agreement on a "low-price" offer. But the proposal does address the "innocence problem" in a broader sense.

To make the context for the proposal concrete, assume that an innocent is charged with armed robbery or distributing twenty kilos of cocaine, and the sentence could be twenty years in prison. Even if the innocent defendant has a ninety-percent chance of acquittal, he might rationally believe it is in his interest to accept a six-month jail sentence rather than face the risk of the twenty-year sentence if convicted at trial. But a judge might balk at accepting such a plea agreement. She might respond: "If the defendant really committed armed robbery [or distributed large quantities of cocaine], as his plea admits, then he should serve ten or fifteen years in prison. If he did not commit the offense, and thinks there are significant chances of establishing that at trial, then he should go to trial and seek an acquittal." Existing law thus creates a "problem" for the innocent because it tends to force trial when the probabilities of conviction are low. The judge's sentencing power can block voluntary transactions and deny the defendant a settlement option that both he and the prosecutor prefer to trial. For Scott and Stuntz it would be efficient to bar interference with such presumptively welfare-enhancing agreements.

The essence of the Scott-Stuntz proposal-no judicial interference with lowsentence plea agreements-is already widely followed in practice, but theory continues to insist that the judge must approve the adequacy of the plea agreement and sentence. ${ }^{58}$ Scott and Stuntz would abandon this pretense, along with the constraining influence it may have in practice, and permit prosecutors to fix a low maximum sentence in return for a plea.

Several consequences would ensue. The costs of processing the innocent would be reduced because fewer of them would elect trial. ${ }^{59}$ As a necessary corollary, more innocents would be convicted, but this would not count as a

57. Id. at 1953-57.

58. See, e.g., FED. R. CRMM. P. 11(e)(4); U.S. SENTENCING COMM'N, FEDERAL SENTENCING GUIDELINES MANUAL $\S 6 B 1.2$ (1992) [hereinafter U.S.S.G.].

59. But this cost reduction could lead to more litigation, even against the innocent, and thus raise overall litigation expenditure. See William M. Landes, Sequential Versus Unitary Trials: An Economic Analysis (Working Paper, University of Chicago, Program in Law and Economics, 1992) (on file with author). 
cost for Scott and Stuntz because each innocent who pleads guilty prefers that outcome to the risk of a high sentence after conviction at trial. The total punishment imposed on innocents as a group might drop (because of their lowprice bargains), but if innocents are highly risk averse, aggregate punishment imposed on the innocent would likely increase. For the economist, however, this effect does not reflect harm to the innocent (though it is a waste of resources for society), because each innocent prefers his situation under the new regime to that of the current world in which judicial intervention (or the prospect of it) forces risk-averse innocents into an unwanted trial.

The claim that interference by judges reduces efficiency is tautological if we posit that voluntary transactions maximize welfare. But the premise is valid only if the contracting parties fully internalize the social costs and benefits of their transaction. This is not the case with respect to plea agreements. Litigation time, criminal conviction, and punishment are public goods with powerful external effects. To assume away these externalities is to produce a "clean" but irrelevant model. The important issues, for an economic analysis, are the nature of the externalities and the value of judicial intervention as a device for monitoring to insure the internalization of social costs.

Two sorts of externalities are particularly relevant here. The first is the public interest in minimizing conviction of the innocent. As discussed above, ${ }^{60}$ the decision of an innocent defendant to plead guilty in return for a low sentence inflicts costs on society, even if the defendant prefers this result, because it undermines the accuracy of the guilt-determining process and public confidence in the meaning of criminal conviction. To make this point is not to say that forcing the innocent defendant to trial is doing him a favor; Scott and Stuntz are correct to point out that denying the settlement option only sharpens the innocent defendant's predicament. ${ }^{61}$ But providing a settlement option does not avoid the dilemma; it merely shifts its costs from the risk-averse individual to society at large. Nothing in economic analysis enables us to conclude that this social harm is outweighed by the advantages to the individual defendant, even under the (problematic) assumption that the individual's preference for a guilty plea is the result of disinterested professional advice based on a thorough investigation of factual and legal defenses.

The second major externality is the risk of inadequate deterrence if prosecutors offer guilty defendants sentences that are too low. Scott and Stuntz acknowledge that judicial oversight could be viewed as a means to correct agency problems in the prosecutorial function. ${ }^{62}$ But they dismiss this possibility because the prosecutor's initial charging decision is not subject to this sort of judicial oversight. Since the prosecutor can choose not to charge at all, they argue, it is odd to constrain him when he seeks only a small penalty.

60. See supra text accompanying notes 24-26.

61. Scott \& Stuntz, supra note 1, at 1960-61.

62. Id. at 1955-56. 
Resort to this kind of axiom (that the greater power should include the lesser) can be valid only if all other considerations remain equal. In this case, they do not. The value of judicial supervision depends on the effects of erroneous decisions, the cost of judicial monitoring, and the availability of alternate mechanisms of control. In all three respects, judicial review of plea agreements is more important and more productive than judicial review of initial charging decisions.

Note first the difference in the costs of erroneous decisions. Though decisions not to charge and decisions to offer very light punishment involve similar damage to crime control interests, they differ radically in terms of the negative externality of convicting the innocent. A decision not to charge does not implicate this concern at all. But a decision to press a weak case and get a conviction with a low sentence does.

Second, insistence that judges must control complete dismissals (the charging decision) if they are to control partial dismissals (plea bargaining) ignores the special difficulties entailed in supervision of the former. Control of charging may on balance be a good idea, ${ }^{63}$ but it poses complex questions of administration and implementation ${ }^{64}$ that are not presented when judges review the adequacy of punishment (a traditional judicial function) in cases that the prosecutor chooses to bring.

Third, charging decisions are monitored and controlled by informal devices that operate much less effectively, or not at all, when the prosecutor negotiates a low-sentence plea. A prosecutorial decision not to charge is constrained by relationships with police officers and victims, by politics in the office, by the prosecutor's own incentives to appear "tough," and by her need to maintain a high rate of conviction. Because a decision not to charge is so much more visible and so much easier to question than a decision about what sentence to recommend in return for a guilty plea, informal pressures can operate far more effectively in connection with charging decisions than they can when the prosecutor assesses the strength of a case and decides to offer a lenient plea agreement. Judicial oversight is far less needed in decisions not to charge than it is in lenient plea bargains.

In sum, judicial power to reject lenient plea agreements can serve a useful function and should, if anything, be invoked more frequently. The proposal to eliminate this oversight authority would make the bargaining system less rather than more efficient and would harm rather than help the innocent.

Thus, none of the three reforms proposed by Scott and Stuntz can mitigate either the special "innocence problem" that their analysis stresses or the innocence problems more traditionally emphasized in criticisms of plea bargaining. The first two Scott-Stuntz proposals are largely innocuous. They have long ago

63. See KENNETH C. DAVIS, DISCRETIONARY JUSTICE 188-214 (1969); James Vorenberg, Decent Restraint of Prosecutorial Power, 94 HARV. L. REV. 1521 (1981).

64. See FranKLIN E. ZIMRING \& RICHARD S. FRASE, THE CRIMINAL JUSTICE SYSTEM 396-456 (1980). 
been implemented in every jurisdiction and cause no harm, but they can do little to remedy the defects of bargaining. The third proposal, however, would aggravate the existing dangers of the plea bargaining system by eliminating one of the few means now available to counteract agency distortions, inadequate punishment, and inadequate protection of innocent defendants from unjustified conviction.

There is another way to address the difficulties of plea bargaining. Why not simply abolish it? The next part assesses this direct approach to the problem.

\section{Serious Reform of the Plea Bargaining System}

I have suggested three reasons why we cannot assume that voluntary contracting will necessarily enhance the welfare of affected parties in plea bargaining. First, condemnation, punishment, and litigation time are public goods with powerful social effects that the prosecution and defense counsel cannot fully internalize in a two-party contractual situation. Second, pervasive conflicts of interest introduce additional agency costs into the negotiating process. Third, no contractual mechanisms permit monitoring or ensure that gains from trade outweigh the agency costs of bargaining through intermediaries.

What reforms might address these problems? As the previous section indicates, one of the Scott-Stuntz reforms-making prosecutorial plea commitments binding on the judge-would only aggravate these problems; the other two-judicial power to impose punishments less severe than the bargained outcome and sentencing regimes that avoid severe mandatory minimums-already exist, and neither one helps mitigate the central flaws in the plea bargaining system. In this part, I consider more ambitious changes: first, incremental reforms; and second, two ways of abolishing bargaining that are worth adopting whether or not the incremental reforms are pursued.

\section{A. Incremental Reforms}

One reform that would directly address the flaws of plea bargaining is expansion of pretrial discovery to something approximating the civil model, so that negotiating parties could more accurately estimate ex ante the likelihood of conviction at trial. ${ }^{65}$ But discovery reforms, though worthwhile, would seldom be put to use unless defense counsel were afforded better capacities and incentives for zealous representation.

65. See, e.g., ILL. ANN. STaT. ch. 110A, paras. 411-415 (1982) (Smith-Hurd 1985) (Supreme Court Practice Rules). 
A more important incremental reform, indeed an imperative one, would restructure the economic relationship between defense attorney and client. At a minimum, involuntary conscription of defense attorneys should be abolished forthwith. Conscription represents such an obvious and flagrant assault on the principles of economic efficiency that it is not a particularly "interesting" object of scholarly attention or theoretical analysis. Yet we must not allow fascination with subtle theoretical impediments to obscure more blatant and consequential problems.

A second step in restructuring defense representation would address the involuntariness of the relationship on the client's side. Despite practical difficulties allegedly entailed in permitting indigent defendants to choose their lawyers, ${ }^{66}$ the case for freedom of contract here is powerful. ${ }^{67}$ My proposal would simply provide each indigent defendant a voucher with which he could hire his own attorney, whether an individual practitioner or a specialized firm of defenders. ${ }^{68}$

Vouchers would substantially mitigate agency problems in the attorneyclient relationship even if no net increase in public funding for indigent defense accompanied the change. Yet when one realizes what such vouchers would be worth at current expenditure levels, the importance of funding decisions becomes impossible to ignore. Current budgetary allocations for indigent defense would permit a poor defendant in New Jersey (our most generous state) to receive a voucher worth $\$ 540$, while a defendant in Arkansas would receive a voucher worth $\$ 63 .^{69}$ These are not hourly rates but the total fee for a case.

Our present methods of indigent defense hide the real value of defense services afforded the indigent and permit discussions of bargaining efficiency to proceed in the abstract. No responsible economist would advocate a plea bargaining system in which indigent defendants were forced to negotiate without professional assistance. Yet to the extent that paltry compensation constrains the effort that attorneys can or will provide, our current system tends to approximate one in which there is no meaningful representation. Again, plea bargaining suffers from a blatant structural flaw that dwarfs in importance the subtle informational asymmetries that allegedly impede efficient contracting.

66. For a summary of the arguments, see LAFAVE \& ISRAEL, supra note 40 , at 547.

67. See Schulhofer, supra note 17, at 61-63.

68. Id, at 61-62.

69. See Bureau of Justice STATISTICS, U.S. DeP'T OF JUSTICE, CRIMINAL DEFENSE FOR THE POOR, 1986 , at 5 (1988). The 1986 data showed an average expenditure per case, nationwide, of $\$ 223$. The average expenditure per case is probably even lower today because budgets for indigent defense have been growing more slowly than the indigent caseload. See Robert L. Spangenberg, We Are Still Not Defending the Poor Properly, 4 CRMM. JUST., Fall 1989, at 10. 


\section{B. Relationships Between Incremental Reform and Abolition}

Reform of defense representation should be a top priority in any program to enhance efficiency and fairness in the criminal justice system. But abolition of bargaining remains justified whether or not indigent defense systems are improved. Even if an ideal system of defense representation were instituted, the remaining flaws of plea bargaining would justify abolition. Conversely, if we retain our present, inadequate system of representation, abolition becomes more essential; abolition would not, as Scott and Stuntz argue, aggravate the plight of the poor.

\section{The Need for Abolition After Defense Representation Problems are Solved}

A system of voluntary contractual relationships between attorney and client, if it avoided prohibitive financial penalties for lawyers who take cases to trial, ${ }^{70}$ would go a long way toward eliminating some of the most glaring problems associated with plea bargaining. But even such an ambitious step would leave two major problems unaddressed: agency costs on the prosecution side and negative externalities resulting from conviction of the innocent.

The first problem cannot be remedied because contractual or market-like mechanisms to control prosecutors are simply not feasible. ${ }^{71}$ On the defense side, effective representation would enable innocent defendants to strike better bargains, but it would not avoid the dilemma in which the innocent defendant, facing a small possibility of conviction on a serious charge, considers it in his interest to accept conviction and a small penalty. The defendant's choice to plead guilty can be rational from his private perspective, but it imposes costs on society by undermining public confidence that criminal convictions reflect guilt beyond a reasonable doubt. An "efficient" system of voluntary contracting for pleas would convict large numbers of defendants who had a high probability of acquittal at trial; indeed, to the extent that innocent defendants are likely to be more risk averse than guilty ones, the former are likely to be overrepresented in the pool of "acquittable" defendants who are attracted by prosecutorial offers to plead guilty. To deal seriously with these problems we must consider complete abolition of plea bargaining.

Scott and Stuntz believe that abolition of bargaining will only aggravate the predicament of innocent defendants ${ }^{72}$ because by hypothesis these defendants prefer certain conviction with a low penalty to the risk of a severe penalty

70. A modest disincentive to elect trial (preferably one borne by the defendant personally) would be defensible as a means of requiring indigents to internalize the litigation costs that a defendant of means would bear.

71. See Schulhofer, supra note 17 , at 63-66.

72. See supra text accompanying note 51 . 
after conviction at trial..$^{73}$ This claim is incorrect, as well as beside the point. It is incorrect because abolition of bargaining cannot leave unaffected the background sentence that an innocent will face in the event of conviction at trial. ${ }^{74}$ It is beside the point because an innocent's preference for bargaining cannot be decisive when his conviction would impose serious costs on others. The social interest in not punishing defendants who are factually innocent justifies a bar on compromise, low-sentence settlements, even if individual defendants would prefer to have that option. ${ }^{75}$

\section{The Impact of Abolition if Indigent Defense Remains Inadequate}

Scott and Stuntz acknowledge shortcomings in our systems for providing indigent defense services, but they believe that abolition would make these problems worse. They reason that although

[a]gency problems no doubt exist in this context ... the more extended the relationship, the greater the magnitude of those problems. In a world of constant resources, the level of justice for the poor and unsophisticated, relative to the level of justice the rich receive, would decline if plea bargaining were abolished. ${ }^{76}$

This pessimistic prediction rests on three unstated assumptions: first, that elimination of bargaining will not affect the level of resources allocated to indigent defense; second, that agency problems affect only what is done in preparation for plea or trial and do not skew the choice between these alternatives; and third, that elimination of bargaining will alter only the "extent of the relationship," while all other factors that influence defense effort remain constant. All three assumptions are incorrect. Thus, abolition of bargaining would substantially improve the position of the indigent even if agency problems remain acute.

The single most serious agency problem on the defense side is that the attorney incurs a severe financial penalty if the case goes to trial. ${ }^{77}$ That prospect can powerfully skew his appraisal of the value of a prosecutor's plea offer and the advice he provides to his client. A prohibition on bargaining protects defendants who would accept a plea offer that was not in their interest,

73. Scott \& Stuntz, supra note 1 , at $1960-61$.

74. Id.

75. See supra text accompanying notes $24-26,60-61$. The social interest in accurate factinding does not require a bar on all guilty pleas, only a bar on concessions large enough to elicit pleas from defendants with a significant chance of acquittal at trial.

76. Scott \& Stuntz, supra note 1 , at 1928.

77. See supra notes 31-37 and accompanying text. For public defenders, the disincentives to go to trial are primarily personal and institutional, but retained counsel and appointed private attomeys who elect trial suffer immediate (and usually dramatic) financial consequences. 
even if the attorney, once forced to trial, would give the same indifferent assistance that he would provide in plea negotiations.

But the shift from plea disposition to trial disposition also has a powerful effect on attorney incentives to devote time and effort to the case. Scott and Stuntz assume that this shift only creates greater opportunities for ineffective performance. "[T]he more extended the relationship, the greater the magnitude of [the] problems." 78 This kind of axiomatic reasoning is helpful only if we know enough about context to be sure that all other relevant factors remain equal. In this instance, the shift from plea negotiation to trial brings profound changes in the attorney's function and in prospects for monitoring. Indeed, since the problem here is to assess the distorting effect of agency problems and prospects for effective control, it seems incomplete to suggest that the only difference between the low-visibility plea process and trials in open court is that the latter last longer.

In plea bargaining, the attorney's role is virtually immune from scrutiny or control. The quality of attorney performance is difficult for both clients and peers to assess; the formal obligations of effective assistance do not, even in theory, require investigation of factual or legal defenses; and retrospective control by suits for malpractice or ineffective assistance are precluded by nearly insuperable doctrinal hurdles. ${ }^{79}$

The shift from plea bargaining to trial renders the attorney's performance highly visible to peers in the courtroom. ${ }^{80}$ This shift also enlarges both the attorney's formal legal obligations of effective assistance and the practical likelihood that they will be taken seriously. ${ }^{81}$ The institutional environment of the trial process thus limits the consequences of the agency problem in ways that are precluded when disposition occurs in a low-visibility plea. The visibility of trial also tends to generate pressure to alleviate the worst inadequacies of indigent defense funding. ${ }^{82}$ Indigents are far more likely to receive conscientious representation when cases are tried in open court than when the attorneys are permitted to settle on the basis of an uninformed guess about the likelihood of conviction.

Thus, even if deeply flawed systems for indigent defense remain common, abolishing bargaining and conducting more trials would not hurt poor defendants. Indeed, the more that indigents face acute problems of involuntary representation, inadequate funding, and pervasive conflicts of interest, the more

78. Scott \& Stuntz, supra note 1 , at 1928.

79. See Stephen J. Schulhofer, Effective Assistance on the Assembly Line, 14 N.Y.U. REV. L. \& Soc. CHANGE 137, 140-43 (1986); Scott \& Stuntz, supra note 1, at 1957-58.

80. See Stephen J. Schulhofer, No Job Too Small: Justice Without Bargaining in the Lower Criminal Courts, 1985 AM. B. FouND. RES. J. 519, 547-49, 560-66 (1986) [hereinafter Schulhofer, Justice Without Bargaining]; Stephen J. Schulhofer, Is Plea Bargaining Inevitable?, 97 HARV. L. REV. 1037, 1067-70, 107375 (1984) [hereinafter Schulhofer, Is Plea Bargaining Inevitable?].

81. See Schulhofer, supra note 79, at 137-40, 144-48; Schulhofer, Justice Without Bargaining, supra note 80 , at $588-89$.

82. See Schulhofer, Justice Without Bargaining, supra note 80 , at 589-90. 
that abolition remains necessary to permit better monitoring of the attorneyclient relationship. The mission of the criminal justice system is to ascertain guilt and appropriate punishment. Structural flaws only increase the importance of resolving these issues in the sunlight of open, adversarial proceedings before a neutral decisionmaker, rather than permitting them to be settled behind closed doors by agents who have few incentives to act in the interests of their principals.

\section{Abolition}

I preface my analysis of abolition with an obvious caveat that is worth making explicit. I have argued that plea bargaining injures the public interest in optimal deterrence, the defendant's interest in accurately assessing the risk of acquittal, and the societal interest in minimizing conviction of the innocent. I also believe that these costs outweigh potential gains from voluntary contracting, but I do not claim that this conclusion is value-free or beyond debate. On the contrary, agency costs (relative to those of alternate arrangements) and the extent of damage from convicting the innocent cannot be determined solely through use of economic theory or any other "objective" analysis. Resolution of these issues requires judgment, informed by a sense of institutional complexities and the dynamics of real-world behavior. Economic claims for the "efficiency" of bargaining, based on a simplified two-party model that ignores agency costs and externalities, are analytically incorrect. But the affirmative branch of my argument, that abolition is preferable, does not purport to avoid questions of assessment and value.

Abolition of plea bargaining can be understood in two senses. It is often equated with the elimination of all incentives to waive trial. I refer to such a program as abolition of concessions. An alternative approach would eliminate only bargaining; it would retain concessions for pleas, but the concessions would be nonnegotiable incentives fixed by statute or rules of court.

In rejecting the abolition approach, Scott and Stuntz assume that abolition would produce an increase in the trial rate, a decrease in the quality of trials, and a consequent increase in the risk of convicting the innocent. ${ }^{83}$ Their argument, though thought-provoking, proceeds from three erroneous premises. First, they assume that abolition requires eliminating concessions entirely. But so long as fixed concessions are retained to preserve the guilty plea rate, abolition of bargaining entails none of the difficulties raised by Scott and Stuntz. Second, abolition of all concessions need not decrease the quality of trials. Third, even if abolition did decrease the quality of trials, it would not increase the overall risk of convicting the innocent in the combined processes of adjudication by plea and by trial. Abolition of bargaining is an attractive, low-cost solution to

83. Scott \& Stuntz, supra note 1, at 1932-34. 
the manifold difficulties of plea bargaining. Abolition of all concessions is also a viable, though somewhat more costly strategy. ${ }^{84}$

\section{Abolition of Bargaining}

By abolishing bargaining but not abolishing concessions, a jurisdiction could retain control over its guilty plea rate and preserve its existing low level of resources committed to trials. Such a system has frequently been proposed; ${ }^{85}$ it was adopted by Italy when it transformed its criminal procedure into an adversary system in $1988 ;{ }^{86}$ and it is approximated, though imperfectly, under the guilty plea provisions of the federal sentencing guidelines. ${ }^{87}$

In such a system, the proportion of defendants pleading guilty would be similar to the present number, but the composition of the guilty plea pool presumably would change. Those who elect trial in the present system do not necessarily have the greatest chance of acquittal because such defendants are also the ones most likely to win the best sentence concessions in negotiation. Rather, those who now go to trial tend to be those who are least risk averse, a group that may include disproportionate numbers of those who are actually guilty. In contrast, in a system of nonnegotiable sentence concessions, defendants who elect trial are most likely to be those with the greatest likelihood of acquittal, a group that should include disproportionate numbers of the innocent. The normative premise of this approach is that the trial process, however infrequently used, should be reserved for cases where guilt is most in doubt.

Abolition of bargaining provides an excellent, low-cost means to control agency problems on the prosecution side and to protect the public from inadequate sentences (at least if bargaining does not reemerge through manipulation of the provable charges ${ }^{88}$ ). Abolition of bargaining also can substantially mitigate agency problems on the defense side and help protect innocents from

84. My analysis focuses on whether abolition of bargaining (and all concessions) is desirable in principle, resource costs included. I do not address the question whether attempts to abolish bargaining will be subverted by front-line practitioners. For empirical research suggesting that subversion can be avoided, see Schulhofer, Is Plea Bargaining Inevitable?, supra note 80 . Recent federal sentencing reforms preserve sentencing concessions but sharply reduce opportunities for bargaining; empirical studies suggest that subversion of these bargaining restrictions currently occurs but that its extent has been contained. See Dene H. Nagel \& Stephen J. Schulhofer, A Tale of Three Cities: An Empirical Study of Charging and Bargaining Practices Under the Federal Sentencing Guidelines, 66 S. CAL. L. REV. (forthcoming 1992); Schulhofer \& Nagel, supra note 48.

85. See, e.g., Robert M. Sussman, Note, Restructuring the Plea Bargain, 82 YALE L.J. 286, 301-02 (1972).

86. CODICE DI PROCEDURA PENALE art. 444 (1988) (Italy) (guilty plea with one-third reduction in applicable sentence, provided that maximum sentence does not exceed two years); $i d$. art. 442 ("abbreviated trial" with one-third reduction in applicable sentence upon conviction; no limitation on maximum term, but defendant may dispute charge and judge must find sufficient evidence to support conviction); see also Ennio Amodio \& Eugenio Selvaggi, An Accusatorial System in a Civil Law Country: The 1988 Italian Code of Criminal Procedure, 62 TEMP. L. REV. 1211, 1219-20 (1989).

87. U.S.S.G., supra note 58; see Schulhofer \& Nagel, supra note 48, at 243-52.

88. See Nagel \& Schulhofer, supra note 84 ; Schulhofer \& Nagel, supra note 48, at 278-82. 
the pressure (or temptation) of extremely lenient plea offers. But this remedy is imperfect because attorneys who suffer financial penalties when their cases go to trial will still be tempted to overestimate the advantages of taking the fixed discount for a plea.

\section{Abolition of Concessions}

This more ambitious reform would generate a large increase in the trial rate and a significant increase in litigation costs. Though one must be quite tentative about offering actual numbers, my study of the Philadelphia courts suggests that elimination of all sentencing concessions for pleas might raise the trial rate from $10-15 \%$ to roughly $75 \%$ of all felony cases. ${ }^{89}$ But with reliance on a system of adversarial trials before a judge sitting without a jury, such a reform would require an increase of only about $20 \%$ in the judicial resources devoted to the adjudication stage; stated as a percentage of total judicial resources, the required increase would be even smaller. ${ }^{90}$

Readers unfamiliar with prior empirical research may wonder how a $650 \%$ increase in the trial rate (from $10 \%$ to $75 \%$ ) could possibly be accomplished with only a $20 \%$ increase in adjudication resources. The answer has several parts. First, nontrial adjudication is itself a lengthy process, requiring a detailed guilty plea colloquy, time to read into the record the factual basis for the plea, and the waiting time necessary to get in-custody defendants to the courtroom. Second, adjudication by bench trial requires relatively little additional time, because the most time-consuming features of the criminal trial-jury selection, introductory and closing statements, jury instructions, recesses, and side bar conferences-are largely a result of the jury system, not of the adversary trial process itself. Finally, the few cases tried before a jury require so much courtroom time that a small percentage increase in available resources can generate a large percentage increase in the court's capacity to adjudicate by bench trial. Based on observed times actually consumed by the alternative case disposition methods, ninety guilty pleas would require an average of 4950 minutes of court time ( 55 minutes each), five bench trials would require 400 minutes ( 80 minutes each), and five jury trials would require 3600 minutes (two days each), a total of 8950 minutes of courtroom time for the 100 cases. With seventy bench trials, five jury trials, and only twenty-five guilty plea dispositions, the total courtroom time required would rise to 10,575 minutes, an increase of only $18 \% .^{91}$

89. Schulhofer, Is Plea Bargaining Inevitable?, supra note 80 , at 1051, 1082 (55\% of cases were tried, and an additional $17 \%$ were guilty pleas induced by some concessions; without concessions, $70-75 \%$ of the defendants would have elected trial).

90. Id. at $1085-86 \& \mathrm{nn} \cdot 160-61$.

91. The calculations are premised on the assumption that $5 \%$ of all cases would be resolved by jury trial and that this figure would remain constant as the jurisdiction moved cases from disposition by guilty plea to disposition by bench trial. Shifting each $10 \%$ segment of the caseload from plea to bench trial would require a 3\% increase in the judicial resources devoted to the adjudication stage. For analysis of the 
Though abolition of bargaining would not require any increase in the trial rate, because fixed inducements to plead guilty could be preserved, abolition would benefit the innocent even if it eliminated all concessions and forced a large increase in trials. The Scott and Stuntz claim of harm to the innocent reflects three assumptions: first, "the error rate of trials would rise . . . at least as long as one assumes a constant level of expenditures on the system"; second, "[b]ecause error rates at trial would be higher, convicting innocents would likely be easier in a no-bargaining world";"93 and third, "the incentives to separate the innocent from the guilty at the charging stage would be reduced." 94 Scott and Stuntz believe that abolishing concessions would harm the innocent because prosecutors might be less likely to screen them out at the charging stage and because once charged, they would more likely be convicted.

The claim that abolishing concessions would harm the innocent is unfounded. Both the underlying assumptions and the conclusion drawn from them are erroneous. First, the assumption of a constant level of expenditures is unwarranted. No responsible proponent of abolishing concessions (as opposed to abolishing bargaining alone) could contemplate implementing such a reform without some increase in resources. One of the central objections to plea bargaining is that it saves court funds, at the expense of more important but intangible values. One cannot refute this argument simply by positing that the resources available to the criminal justice system are fixed.

If abolition of concessions were accompanied by a twenty-percent increase in adjudication resources, the error rate of trials would not necessarily rise. The Philadelphia experience indicates that expeditious but fully adversarial bench trials can proceed with thorough preparation by both sides ${ }^{95}$ and can afford adequate time for determinations that roughly mirror the results of a jury trial. ${ }^{96}$ Though Scott and Stuntz correctly cite the Philadelphia data for the proposition that "most" such trials take less than an hour," it does not follow that the trials entail a high error rate. The short trials that Scott and Stuntz cite occurred in a court program limited to cases involving simple charges with few

resources required to eliminate plea concessions in misdemeanor cases, see Schulhofer, Justice Without Bargaining, supra note 80 , at $574-77$ (move from $10 \%$ to $50 \%$ trial rate in misdemeanor cases could require $25 \%$ increase in court resources devoted to adjudication stage).

92. Scott \& Stuntz, supra note 1, at 1932.

93. Id. at 1933.

94. Id.

95. See Schulhofer, Is Plea Bargaining Inevitable?, supra note 80, at 1064-65. Although Scott and Stuntz cite the above study for the proposition that "pretrial preparation on both sides was minimal," Scott \& Stuntz, supra note 1, at 1950, the pages they cite contain no discussion of preparation, and the relevant portions of the article make precisely the opposite point: preparation was quite thorough for defenders; trial prosecutors, though more pressed for time, could draw on substantial preparation by colleagues at the preliminary hearing stage. Schulhofer, Is Plea Bargaining Inevitable?, supra note 80, at 1056-57.

96. Schulhofer, Is Plea Bargaining Inevitable?, supra note 80 , at 1083-84. The Philadelphia model entails preservation of jury trial for any defendants unwilling to waive that right. The availability of the jury trial option undoubtedly constrains (though it does not wholly eliminate) tendencies toward careless factfinding or dilution of the reasonable doubt requirement in the bench trial system.

97. Scott \& Stuntz, supra note 1 , at 1950. 
witnesses. True, "most" such cases (69\%) were resolved in under an hour, but even for these simple cases, $31 \%$ were afforded longer hearings. ${ }^{98}$ In the court program for more complex cases, only $24 \%$ of the bench trials took under an hour, and $36 \%$ took more than two hours. ${ }^{99}$

If the resources available for trial did not grow or did not grow enough, and if the quality of bench trials therefore declined, abolition still would not hurt the innocent. Scott and Stuntz assume that "[b]ecause error rates at trial would be higher, convicting innocents would likely be easier in a no-bargaining world." 100 This is a non sequitur. The flaw in their analysis results from comparing apples with oranges-the error rate of the entire adjudicatory system of a no-bargaining world with the error rate in just the fanciest part of a system with bargaining. A no-bargaining world with high rates of trial error might convict innocents who would have been acquitted in jury trial. But a bargaining world would not afford these defendants a jury trial; it would induce them to accept plea contracts in which conviction was a virtual certainty. ${ }^{101}$ When the entirety of each system's conviction modes is included, convicting the innocent is unequivocally easier in a world that permits plea bargaining.

The changes resulting from abolition of concessions would also affect the charging decision, but not in the way that Scott and Stuntz predict. Because processing each case would be more costly, and because innocents would be more difficult to convict, the prosecutor's incentives (both personal and public) to screen carefully at the charging stage would be enhanced. The total number of defendants charged might decrease if prosecutorial resources were held constant. But even if the number charged did not decline, the proportion of innocents in the pool of defendants would tend to decrease. In addition, fewer of those defendants would be convicted because the streamlined trial process, even if it had a high error rate, still would generate more acquittals than the bargaining process does.

Though abolishing concessions would help many innocents, it might appear to hurt others. Because abolition would make it harder to convict the innocent, it would benefit defendants convicted in the plea bargaining process who would not be convicted, and perhaps would not even be charged, in a no-concessions world. But some innocents would be convicted under either regime, and it

98. Schulhofer, Is Plea Bargaining Inevitable?, supra note 80, at 1066.

99. Id.

100. Scott \& Stuntz, supra note 1 , at 1933.

101. My analysis assumes that abolition of all concessions for pleading guilty would not require abolition of jury trial or reduction of its caseload share. See supra notes 91,96 . Cases would shift from guilty plea disposition, where conviction is certain, to disposition by bench trials which, even if flawed, would afford some chance for acquittal. If the flawed bench trials cost more than the guilty plea dispositions, and if total resources remained fixed, jury trials would not have to be viewed as the only funding resource, and their quality would not have to suffer. The necessary additional funds (which would likely be slight) could come from reducing the total caseload, screening cases more carefully, or restricting court activity at numerous other points in the civil or criminal system. If such cuts were too painful, the short answer would be to avoid them by accepting the needed (and modest) increase in resources. 
might seem that this subset of the innocent would face longer sentences in the no-concessions world. This is not necessarily the case, however. As we have seen, ${ }^{102}$ typical posttrial sentences in a no-concessions world could not be as long as typical posttrial sentences imposed today; the former would most likely approximate typical sentences imposed today in the ninety percent of cases resolved by guilty plea. Innocents who received such sentences after conviction at trial would be no worse off than innocents who receive a sentence "discount" for pleading guilty in today's world of bargaining.

A few innocents, a subset of the previous subset, may now draw less than the "typical" sentence, because their low probability of conviction enables them to negotiate an especially favorable deal. But in plea bargaining, innocent defendants are not necessarily the ones most likely to win below-average sentences. Rather, below-average sentences tend to occur in cases involving reluctant prosecutors, defendants who are least risk averse, defense attorneys who most credibly threaten to elect trial, and evidentiary weaknesses that are apparent before trial, all factors that correlate imperfectly and to some extent inversely (in the case of risk preference) with actual innocence.

In sum, there is no reason to believe that a no-concessions world would disadvantage innocents as a group. Even the subset of innocents who would be convicted in a no-concessions world would not be systematically worse off than they are in regimes that permit bargaining. Error cannot be entirely precluded by abolition of concessions, or by any other reform. But the essential point is that in a no-concessions world, convictions and sentences would result from our best efforts to ascertain the actual facts of the individual case. In plea bargaining, error is more than just a risk. It is an inherent feature of the system because the plea process does not seek to separate guilty from innocent individuals but only applies the law of averages to groups of cases, sorted by rough guesses about what investigation or cross-examination, if conducted, might reveal. Such a process inevitably makes erroneous convictions and sentences more likely than when a case is decided on the basis of testimony of witnesses to the particular event, tested in open court with all the truth-checking devices of a vigorous adversary procedure.

\section{CONCLUSION}

Some students of plea bargaining view the process as advantageous to prosecutors, while others stress its benefits for the defense. A basic insight of economic analysis is that these perspectives are not necessarily inconsistent. We do not live in a zero-sum world. Contractual exchange, under appropriate conditions, can leave both parties better off. But the converse is also true. When

102. See supra text accompanying note 52 . 
the conditions necessary for welfare-enhancing transactions are not met, contractual exchange can leave both parties worse off.

In criminal justice, pervasive structural impediments to efficient, welfareenhancing transactions have produced just this situation. With trials in open court and deserved sentences imposed by a neutral factfinder, we protect the due process right to an adversarial trial, minimize the risk of unjust conviction of the innocent, and at the same time further the public interest in effective law enforcement and adequate punishment of the guilty. But plea negotiation simultaneously undercuts all of these interests. The affected parties are represented by agents who have inadequate incentives for proper performance; prospects for effective monitoring are limited or nonexistent; and the dynamics of negotiation can create irresistible pressure for defendants falsely to condemn themselves. As a result, plea agreements defeat the public interest in effective law enforcement at the same time that they deny defendants the benefits of a vigorous defense and inflict undeserved punishment on innocents who could win acquittal at trial.

Plea bargaining is a disaster. It can be, and should be, abolished. 
